\title{
Philosophizing Subsistence
}

\author{
Boghos Artinian* \\ Lebanese Order of Physicians, Lebonan \\ *Corresponding author: Boghos Artinian, Lebanese Order of Physicians, Lebonan
}

\begin{tabular}{|c|c|}
\hline ARTICLE INFO & ABSTRACT \\
\hline Received: 幽 September 19, 2019 & Citation: Boghos Artinian. Philosophizing Subsistence. Biomed J Sci \& Tech Res \\
\hline Published: 䋘 October 04, 2019 & 21(5)-2019. BJSTR. MS.ID.003654. \\
\hline
\end{tabular}

\section{Introduction}

The nourishment of one species (excluding plants) almost always involves the destruction of another - the one consumed. The prey has to be killed before entering the innards of the predator. Or, if swallowed alive, it would soon suffocate* and be digested to simple molecules. Even the large molecules (proteins) we consume must 'die' (be split) before crossing the intestinal barriers to enter the new 'kingdom' they are destined to serve. Thus, if we want to avoid harming any 'beings' as we eat, we must seek prey that could enter our circulatory system without being altered; amino acids, lipids, sugars, electrolytes, trace elements and vitamins. These nutriments, however, are molecules and therefore stand at three levels of organization below our level- the intervening levels being the cellular and the organellar levels - and they are expensive and unhealthy to consume alone. Man must not naively assume that he is on the top of the food chain in the universe simply because he happens to enjoy such a privilege here on earth (with the exception of some unfortunate people who are occasionally devoured by carnivores). Once a multi-humanoid super-organism is discovered in outer space, we must immediately assume it is capable of devouring us until proven otherwise. In all likelihood we would be considered useless, in the living state, to super-organisms. Even our cells may have to be digested and perhaps only our organelles may be allowed to enter intact. therefore alive. The single situation whereby we may be incorporated in a super-organism in the living state is when we are being used as a transplant in that superorganism for a specific function, not unlike that of bone marrow cells transfused live into a human being suffering from leukemia.
The most horrible demonstration, so far, of what a superorganism is capable of doing to humanity has unfortunately been performed during the Holocaust when the Third Reich -- a primitive earthbound super-organism of Hitler's creation, mercilessly took the lives of millions and shamelessly extracted their gold toothfillings, their fat, their bones and possibly other body components for commercial purposes. A super-organism may be successfully diverted from devouring human beings under certain special circumstances-- if we, as a primitive super-organism (society), reached an understanding with it. In that case we would have to pay a certain tax to be kept alive. The cow is a good example of such an arrangement at our level-- it gives us milk (molecules) in exchange for being fed and kept alive until it reaches a ripe age. A similar understanding with a super-organism would have to he reached in outer space where, unlike on earth, human beings could face their foes as super-organisms themselves. As individuals we would not be a match for super-organisms, and they could easily enslave us as we enslave yeast cells for the manufacture of all sorts of industrial products, foods and medicines; we would be totally subject to their vagaries. I have to stop philosophizing here; it is almost noon and I smell the seductive aroma of a steak emanating from the kitchen. I am hungry, thus my concern for the well-being of other organisms is at its ebb. I am a carnivore, yet I dare hope that a 'hungry' superorganism would 'think' about its subsistence in a radically different manner. *Some turtles are known to be able to eat their way out of the guts of sharks after being swallowed. 


\section{ISSN: 2574-1241}

DOI: 10.26717/BJSTR.2019.21.003654

Boghos Artinian. Biomed J Sci \& Tech Res

(c) (i) This work is licensed under Creative

Submission Link: https://biomedres.us/submit-manuscript.php

$\begin{array}{ll}\text { BIOMEDICAL } & \text { Assets of Publishing with us } \\ \text { RESEARCHES } & \text { Global archiving of articles } \\ \text { - Immediate, unrestricted online access }\end{array}$

